\title{
Genetic and epigenetic analyses of panic disorder in the post-GWAS era
}

\author{
Yoshiro Morimoto $^{1,2}\left(\mathbb{D} \cdot\right.$ Shinji Ono $^{3} \cdot$ Naohiro Kurotaki $^{4} \cdot$ Akira Imamura $^{2} \cdot$ Hiroki Ozawa $^{1,2}$
}

Received: 29 January 2020 / Accepted: 3 May 2020 / Published online: 9 May 2020

(c) The Author(s) 2020

\begin{abstract}
Panic disorder (PD) is a common and debilitating neuropsychiatric disorder characterized by panic attacks coupled with excessive anxiety. Both genetic factors and environmental factors play an important role in PD pathogenesis and response to treatment. However, PD is clinically heterogeneous and genetically complex, and the exact genetic or environmental causes of this disorder remain unclear. Various approaches for detecting disease-causing genes have recently been made available. In particular, genome-wide association studies (GWAS) have attracted attention for the identification of disease-associated loci of multifactorial disorders. This review introduces GWAS of PD, followed by a discussion about the limitations of GWAS and the major challenges facing geneticists in the post-GWAS era. Alternative strategies to address these challenges are then proposed, such as epigenome-wide association studies (EWAS) and rare variant association studies (RVAS) using next-generation sequencing. To date, however, few reports have described these analyses, and the evidence remains insufficient to confidently identify or exclude rare variants or epigenetic changes in PD. Further analyses are therefore required, using sample sizes in the tens of thousands, extensive functional annotations, and highly targeted hypothesis testing.
\end{abstract}

Keywords Panic disorder · Genome-wide association studies (GWAS) $\cdot$ Missing heritability $\cdot$ Next-generation sequencing (NGS) - Rare variant association study (RVAS) · Epigenome-wide association study (EWAS)

\section{Introduction}

Panic disorder (PD) is an anxiety disorder characterized by recurrent and unexpected panic attacks, subsequent anticipatory anxiety, and phobic avoidance. Approximately, 10-20\% of patients with PD are refractory, with severe and chronic symptoms that seriously affect their quality of life (Markowitz et al. 1989). PD has a high incidence rate, with a lifetime prevalence of $1-3 \%$, and is a disorder frequently observed in clinical practice (Wittchen et al. 2011). Several genetic and

Yoshiro Morimoto

y-morimoto@nagasaki-u.ac.jp

1 Department of Neuropsychiatry, Unit of Translation Medicine, Nagasaki University Graduate School of Biomedical Sciences, Sakamoto 1-7-1, Nagasaki 852-8501, Japan

2 Child and Adolescent Psychiatry Community Partnership Unit, Nagasaki University Hospital, Nagasaki, Japan

3 Aino-Ariake Hospital, Unzen, Nagasaki, Japan

4 Department of Clinical Psychology, Faculty of Medicine, Kagawa University, Kagawa, Japan epidemiological studies, including family and twin studies, have shown that genetic factors play an important role in the pathogenesis of PD. First-degree relatives of a proband with PD are at a sixfold risk of developing this disease (Goldstein et al. 1997). Additionally, the PD concordance rate is higher in monozygotic twins than in dizygotic twins (Hettema et al. 2001). Conventionally, linkage mapping enables us to identify the causative genetic variants of Mendelian diseases, such as Huntington's disease, using polymorphic microsatellite markers. However, neuropsychiatric disorders, including $\mathrm{PD}$, are typically not caused by single mutations; therefore, traditional linkage mapping for neuropsychiatric disorders have not achieved the same success as they have for Mendelian diseases (Karayiorgou and Gogos 2006; Venken and Del-Favero 2007). Various candidate gene association studies have been conducted to identify candidate genes for neuropsychiatric disorders, including PD, but few studies have demonstrated reproducible results (Singer 2009; Schumacher et al. 2011).

In recent years, with rapid advances in sequencing technology, large amounts of data can be obtained and various approaches are available to detect disease-causing genes. 
In particular, genome-wide association studies (GWAS) have attracted attention for their ability to detect diseaseassociated loci of multifactorial disorders. The GWAS era has been successful in the sense that many loci have been statistically associated with risks for multifactorial diseases, and a large number of these loci have been well replicated (Uniken Venema et al. 2017; Langenberg and Lotta 2018; Dennison et al. 2019).

In the present review, an overview of GWAS of PD is provided, followed by a description of the current and future efforts that are necessary to overcome the remaining issues.

\section{GWAS of PD}

Several GWAS of PD have been published thus far. Otowa et al. (2009) conducted a GWAS in 200 Japanese patients with PD and 200 healthy individuals and identified seven genome-wide significant loci. However, the associations that were found in this 2009 study could not be confirmed in a later reproduction analysis by the same group (Otowa et al. 2010). In the 2010 study, another GWAS was performed, using a larger sample size (718 patients with PD and 1717 controls), and the results of the meta-analysis were reported. Although genome-wide significant single nucleotide polymorphisms (SNPs) were not detected in either the GWAS or the meta-analysis, suggestive associations were observed in several loci, such as the bradykinin receptor $\mathrm{B} 2(B D K R B 2)$ gene $\left(p=1.3 \times 10^{-5}\right.$, odds ratio $(\mathrm{OR})=1.31)$ (Otowa et al. 2012). Erhardt et al. (2011) conducted a GWAS in 216 patients with PD and 222 controls, and reported that genome-wide significant SNPs were not detected, but that the highest nominal association was found for rs7309727 $\left(p=5.1 \times 10^{-7}\right.$, Cochran-Armitage test for trend: $p=7.726 \times 10^{-7}$ ) in discovery samples. In a subsequent replication analysis with a larger number of samples, they found an association between the two SNP haplotypes (rs7309727 and rs11060369) in the transmembrane protein 132D (TMEM132D) gene $\left(p=1.2 \times 10^{-7}\right)$; however, the $p$ value did not reach genome-wide significance. Moreover, when comparing a mouse model of extremes in trait anxiety with normal mice, nominally significant differences were observed in Tmem132d mRNA expression in the cingulate cortex using a microarray experiment $(p=0.004)$. Additionally, rs13478518, which is located on exon 9 of Tmem132d, was reported to be associated with the percentage of time spent in the open arms of the elevated plus-maze test $(p<0.01)$ (Erhardt et al. 2011). The same group conducted a reproduction analysis using an additional PD case-control sample, and found an association between the risk haplotypes and the disorder; however, this association was not observed in an analysis of a Japanese population sample (Erhardt et al. 2012). Additionally, Deckert et al. (2017) conducted a GWAS with a high-dimensional phenotype:
PD with and without agoraphobia (AG)-related anxiety phenotype, based on the Agoraphobia Cognition Questionnaire (ACQ). This study was conducted in a sample of 1370 healthy German volunteers, and a genome-wide significant association was found between rs78726293 and rs19126060 in the glycine receptor beta $(G L R B)$ gene (rs78726293: $\left.p=3.3 \times 10^{-8}, \mathrm{rs} 191260602: p=3.9 \times 10^{-8}\right)$. The authors followed up on this finding in a larger dimensional ACQ sample $(n=2547)$ and in independent samples with a dichotomous AG phenotype based on the Symptom Checklist $(n=3845)$ and a case-control sample with the categorical phenotype PD/AG $\left(n_{\text {combined }}=1012\right)$. Highly significant $p$ values were obtained for rs17035816 $\left(p=3.8 \times 10^{-4}\right)$ and rs7688285 $\left(p=7.6 \times 10^{-5}\right)$ in GLRB. Furthermore, heterozygous Glrb knockout mice showed significantly enhanced agoraphobic behavior, demonstrated by less time spent in the center of the open field test (Deckert et al. 2017). Forstner et al. (2019) conducted a GWAS in 2248 patients and 7992 controls, which is the largest sample size to date, but did not find any loci with genome-wide significant associations. They conducted a follow-up analysis on 255 SNPs $\left(p<1 \times 10^{-4}\right)$ in another independent sample (2408 patients and 22,847 controls) and found that rs 144783209 in the SMAD family member 1 (SMADI) gene had the strongest association with $\operatorname{PD}\left(p_{\text {comb }}=3.10 \times 10^{-7}\right)$ (Forstner et al. 2019).

Table 1 summarizes a list of candidate disease-related loci identified by GWAS.

\section{Results and limitations of GWAS}

Overall, GWAS have yielded exciting results and revealed unexpected candidate genes that contribute to the risk of PD. Several candidate genes are reported to be associated with other mental disorders, and further functional analyses or clinical applications are expected (Table 1).

To date, however, replicated genome-wide significant findings have not been identified in PD case-control GWAS. Given that genome-wide significant loci have been reported in other anxiety phenotypes (Stein et al. 2017; Meier and Deckert 2019; Purves et al. 2019), the PD GWAS that have so far been reported may be underpowered. An expansion in scale at multiple levels may improve GWAS power. First, because sample size is the primary limitation in risk variant discovery, large sample sizes are expected to result in the identification of additional candidate loci (Visscher et al. 2017). Second, performing GWAS in understudied ethnic groups will be informative, especially for detecting ethnicspecific risk variants (Morris 2011; Li and Keating 2014; Medina-Gomez et al. 2015). Third, the use of innovative GWAS methods and study designs, such as GWAS using Bayesian analysis (Stephens and Balding 2009), GWAS using machine learning approaches (Szymczak et al. 2009), 


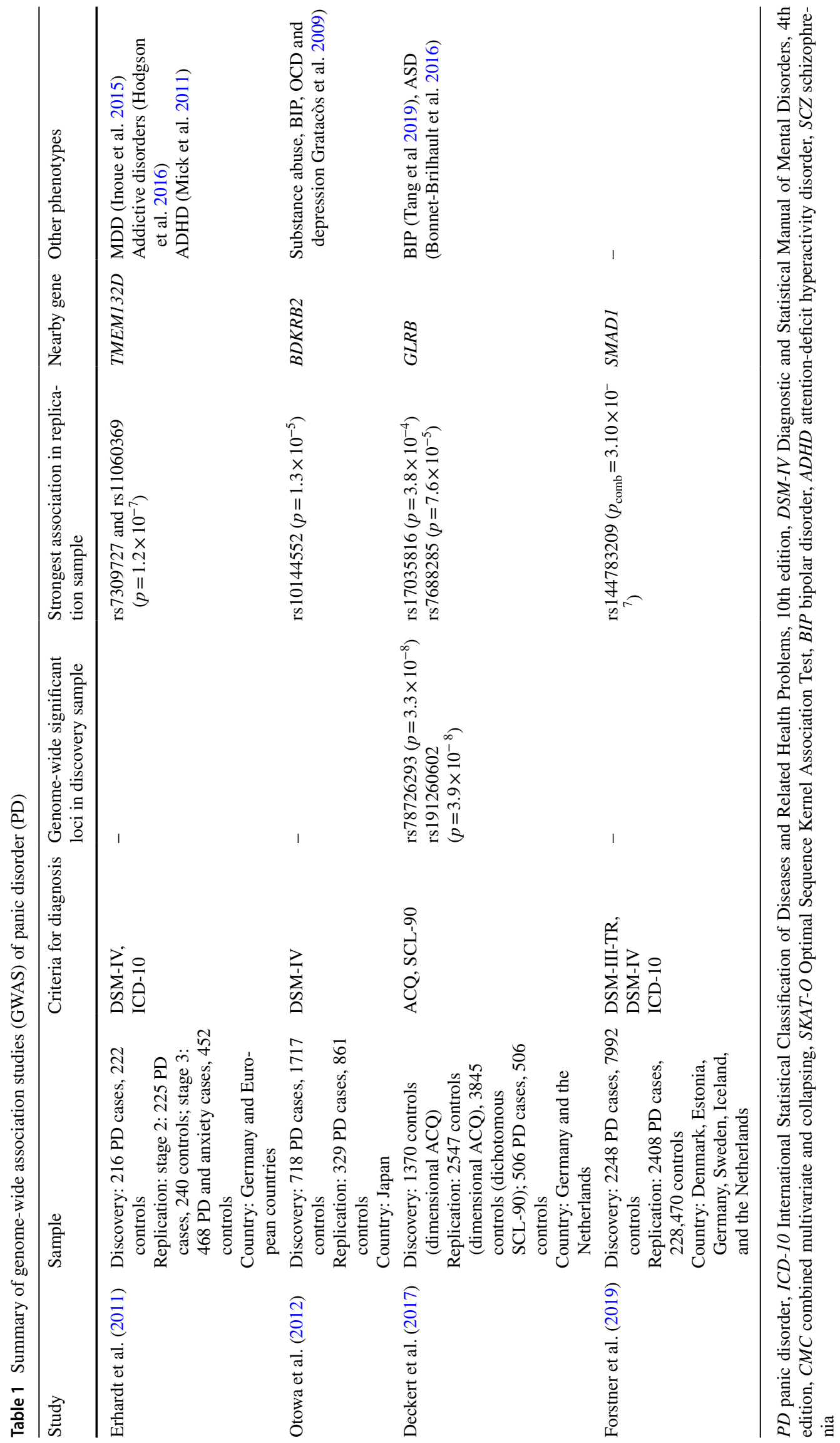


and GWAS using methods to improve power to analyze heterogenous traits, may also lead to the discovery of previously undetected associations (Bhattacharjee et al. 2012).

The value of GWAS lies not only in their utility for identifying disease-associated loci, but also in other applications. For example, polygenic risk scores, which are quantitative measures of risk summed across multiple risk alleles, allow us to separate a population into categories with sufficiently distinct risks, which can then be used for clinical decisionmaking (Tam et al. 2019). The value of a potential polygenic risk score in mental disorders has been explained in several studies (Gasse et al. 2019; Abdulkadir et al. 2019), and it is expected that this will have future applications in PD. Furthermore, using summary statistics from GWAS, linkage disequilibrium score regression (LDSR) can be used to estimate genetic correlations between separate traits (BulikSullivan et al. 2015). Using LDSR, the genetic correlation between PD and anxiety-related traits has been reported. Otowa et al. (2016) conducted a meta-analysis on nine sample sets ( $>18,000$ patients) comprising anxiety disorders (ADs), PD, and phobias, and found a significant correlation of genetic risk between ADs and major depressive disorder (MDD), but not between ADs and bipolar disorder or schizophrenia. Forstner et al. (2019) also reported a significant genetic correlation between PD and MDD, depressive symptoms, and neuroticism. These results suggest that ADs, $\mathrm{PD}$, and MDD are likely to have genetic overlap and continuous phenotypes.

The use of GWAS has identified an unprecedented number of genetic variants associated with common disease traits, but aside from a few notable exceptions, these variants account for only a modest proportion of the estimated heritability of most complex traits (Tam et al. 2019). This hidden heritability, known as "missing heritability," is largely attributed to the limitations of GWAS (Maher 2008). A number of possible explanations for this missing heritability problem include the presence of rare pathogenic variants (Zuk et al. 2014; Bandyopadhyay et al. 2017), epigenetic factors (Trerotola et al. 2015; Bourrat et al. 2017), and the complexity of patient phenotypes (van der Sluis et al. 2010).

In particular, rare variant association studies (RVAS), made possible by the popularization of next-generation sequencing (NGS), are anticipated to cause a paradigm shift to resolve the issue of missing heritability.

\section{RVAS of PD}

NGS has been put into practical use since the early 2000 s. With the adoption of sequencing technology that is completely different from conventional Sanger sequencing, the speed of genome sequencing has dramatically increased. With the popularization of NGS, rare genetic variants-variants that are present with a minor allele frequency of less than 1\%-with a strong effect size have become identifiable by whole genome sequencing (WGS) and whole exome sequencing (WES). Analyses of neuropsychiatric disorders using NGS have been performed (Sanders 2019; Zhuo et al. 2019), and genes with high ORs have been reported (Fromer et al. 2014; Takata et al. 2014; Singh et al. 2016; McCarthy et al. 2017). NGS is a powerful tool to detect genes that cause not only single-gene disorders, but also multifactorial disorders; however, only a few studies have explored the genes responsible for PD.

Gregersen et al. (2016) conducted WES in 54 patients with PD and 211 controls from a Faroe population. However, no genes had a genome-wide significant association with the disorder. The diacylglycerol kinase eta $(D G K H)$ gene demonstrated the strongest association (combined multivariate and collapsing $(\mathrm{CMC}): p=1.25 \times 10^{-4}$ ) with $\mathrm{PD}$ (Gregersen et al. 2016). Additionally, our group performed WES on one Japanese family, including multiple patients with PD, and identified seven candidate genes. We subsequently conducted an association study on the identified candidate genes using a sample of 952 Japanese and 192 German individuals. Genes demonstrating a significant association with PD were not identified; however, the phospholipase A2 group IVE (PLA2G4E) gene had the strongest association (CMC: $p=0.0715$; Madsen-Browning: $p=0.0658$; optimal sequence kernel association test: $p=0.1624$ ) (Morimoto et al. 2018).

Table 2 summarizes a list of candidate genes identified by RVAS.

\section{Limitations of RVAS}

Analyses using NGS have the potential to identify highly pathogenic genetic variants that are difficult to identify using GWAS. In particular, $D G K H$ is reported to be associated with other mental disorders, and further clinical applications are expected (Table 2). However, rare variant analysis using NGS has various issues. Genomic variants that substantially contribute to disease development are expected to have very low allele frequencies; therefore, a relatively large sample size is necessary, or the analyses will lack sufficient power to support the study findings (Moutsianas et al. 2015). Additionally, RVAS requires investigators to test a diverse array of genetic hypotheses that differ in the number, frequency, and effect sizes of underlying causal variants. Thus, extensive functional annotation or highly targeted hypothesis testing is also required to be able to confidently identify rare variants in complex diseases (Moutsianas et al. 2015). The sampling of individuals with extreme phenotypes can enrich the presence of causal rare variants, leading to the increased power of RVAS with complex traits compared with random sampling (Barnett et al. 2013). 
Table 2 Summary of rare variant association studies (RVAS) of panic disorder (PD)

\begin{tabular}{|c|c|c|c|c|c|}
\hline Study & Sample & Criteria & $\begin{array}{l}\text { Gene-based } \\
\text { association } \\
\text { analysis }\end{array}$ & Strongest association & Other phenotypes \\
\hline Gregersen et al. (2016) & $\begin{array}{l}54 \text { PD cases, } 211 \text { controls } \\
\text { Country: Denmark } \\
\text { (Faroe Islands) }\end{array}$ & ICD-10 & - & $\begin{array}{l}D G K H \\
\left(\mathrm{CMC}: p=1.25 \times 10^{-4}\right)\end{array}$ & $\begin{array}{l}\text { BIP (Baum et al. 2008; Zeng } \\
\text { et al. 2011; Yosifova et al. } \\
\text { 2011), depression (Weber } \\
\text { et al. 2011), ADHD (Weber } \\
\text { et al. 2011), SCZ (Zeng } \\
\text { et al. 2011) }\end{array}$ \\
\hline Morimoto et al. (2018) & $\begin{array}{l}\text { Discovery: One Japanese } \\
\text { family including multiple } \\
\text { patients with PD } \\
\text { Replication: } 477 \text { PD cases, } \\
667 \text { controls } \\
\text { Country: Japan and Ger- } \\
\text { many }\end{array}$ & $\begin{array}{l}\text { ICD-10 } \\
\text { DSM-IV }\end{array}$ & - & $\begin{array}{l}\text { PLA2G4E }(\mathrm{CMC}: \\
p=0.0715 ; \text { Madsen- } \\
\text { Browning: } p=0.0658 \\
\text { SKAT-O: } p=0.1624)\end{array}$ & - \\
\hline
\end{tabular}

\section{Epigenome-wide association studies (EWAS) of PD}

Epigenetics is involved in various biological phenomena, including gene expression and cell differentiation (Portela and Esteller 2010). Epigenetic mechanisms, such as DNA methylation, have been suggested to play an important role in disease pathogenesis at the intersection of genetic and environmental factors (Klengel and Binder 2015; Schiele and Domschke 2018), and may be a possible explanation for missing heritability (Trerotola et al. 2015; Bourrat et al. 2017).

Recently, with advances in genome analysis technology, EWAS have become possible (Flanagan 2015). EWAS can be used to analyze genome-wide associations between epigenetic changes and disorders, and several EWAS for multifactorial disorders, including mental disorders, have been reported (Abdulrahim et al. 2019; Starnawska et al. 2019; Gonzalez-Jaramillo et al. 2019).

Iurato et al. (2017) conducted an EWAS in a sample of 89 patients with PD and 76 controls. In the female sample, one locus with genome-wide association was detected in the enhancer region of the hdc homolog, cell cycle regulator $(H E C A)$ gene $\left(\operatorname{cg} 07308824: p=1.094 \times 10^{-7} ; p\right.$-adj $\left.=0.046\right)$. Hypermethylation at the same locus was also confirmed in a reproduction analysis $(p=0.035 ; 131$ patients with PD and 169 controls). Methylation at this $\mathrm{CpG}$ site was associated with HECA mRNA expression in another independent female sample $(n=71)$, both at baseline $(p=0.046)$ and after induction by dexamethasone $(p=0.029)$ (Iurato et al. 2017). Furthermore, Shimada-Sugimoto et al. (2017) analyzed DNA methylation levels at $\mathrm{CpG}$ sites across the genome in a sample of 48 patients with PD and 48 controls. Forty $\mathrm{CpG}$ sites had a significant association with PD, and pathway analysis revealed an association with PD among multiple pathways, including that of positive regulation of lymphocyte activation (Shimada-Sugimoto et al. 2017).
Additionally, Ziegler et al. (2019) conducted an EWAS in a sample of 57 patients with PD and 61 controls. Epigenomewide significant hits were not identified; however, suggestive evidence was observed for decreased methylation at cg 19917903 in the cilia- and flagella-associated protein 46 (CFAP46) gene. These authors also reported DNA methylation changes as well as clinical effects after 6 weeks of cognitive behavioral therapy in PD, but they did not obtain a hit reaching epigenome-wide significance; however, in patients who responded to cognitive behavioral therapy, there was the most suggestive evidence for methylation at CG06943668 in intron 1 of the interleukin 1 receptor type 1 (ILIRI) gene (Ziegler et al. 2019).

Table 3 summarizes a list of candidate disease-related loci identified by EWAS.

\section{Limitations of EWAS}

EWAS have the potential to identify epigenetic changes, which are difficult to detect using conventional technology. In light of the dynamic nature of epigenetic modifications in response to environmental input, recent studies have placed a particular focus on epigenetic changes in relation to the effects of psychotherapy, examining the potential of epigenetic patterns to predict therapeutic correlates of clinical change over the course of psychotherapeutic and preventive interventions (Tomasi et al. 2019; Schiele et al. 2020). As mentioned in the previous section, Ziegler et al. (2019) reported increased methylation at cg06943668 in ILIRI in treatment responders after cognitive behavioral therapy; this finding suggests that diagnostic or therapeutic biological markers of PD may be identified by EWAS.

To date, however, a replicated epigenome-wide significant finding has not been identified in PD using EWAS. All EWAS reports have been conducted on small sample 
Table 3 Summary of epigenome-wide association studies (EWAS) of panic disorder (PD)

\begin{tabular}{|c|c|c|c|c|c|c|c|}
\hline Study & Sample & Criteria & Tissue & $\begin{array}{l}\text { Epigenome-wide sig- } \\
\text { nificant site }\end{array}$ & Strongest association & Nearby gene & $\begin{array}{l}\text { Other } \\
\text { pheno- } \\
\text { types }\end{array}$ \\
\hline Iurato et al. (2017) & $\begin{array}{l}\text { Discovery: } 89 \text { PD } \\
\text { cases, } 76 \text { controls } \\
\text { Replication: } 131 \mathrm{PD} \\
\text { cases, } 169 \text { controls } \\
\text { Country: Germany }\end{array}$ & DSM-IV & Blood & $\begin{array}{l}\text { cg07308824 } \\
\text { hypermethylated } \\
\left(p=1.094 \times 10^{-7}\right) \\
\text { Statistical significance: } \\
\text { FDR of } 5 \%\end{array}$ & $\begin{array}{l}\operatorname{cg} 073088 \\
\text { Hypermethylated } \\
\left(p=1.651 \times 10^{-8}\right)\end{array}$ & HECA & - \\
\hline $\begin{array}{l}\text { Shimada-Sugimoto } \\
\text { et al. (2017) }\end{array}$ & $\begin{array}{l}48 \text { PD cases, } 48 \\
\text { controls } \\
\text { Country: Japan }\end{array}$ & DSM-IV & Blood & $\begin{array}{l}40 \text { CpG sites } \\
\text { Statistical significance: } \\
\text { FDR of } 5 \%\end{array}$ & $\begin{array}{l}\qquad \operatorname{cg} 252704 \\
\text { Hypomethylated } \\
\left(p=5.67 \times 10^{-10}\right)\end{array}$ & METRNL & - \\
\hline Ziegler et al. (2019) & $\begin{array}{l}57 \text { PD cases, } 61 \\
\text { controls } \\
\text { Country: Germany }\end{array}$ & DSM-IV & Blood & $\begin{array}{l}- \\
\text { Statistical significance: } \\
\quad p<5.77 \times 10^{-8}\end{array}$ & $\begin{array}{l}\quad c g 199176 \\
\text { Hypomethylated } \\
\left(p=3.8 \times 10^{-7}\right)\end{array}$ & С CFAP46 & - \\
\hline
\end{tabular}

$P D$ panic disorder, DSM-IV Diagnostic and Statistical Manual of Mental Disorders, 4th edition, FDR false discovery rate

sizes and may therefore have low statistical power. Tsai and Bell (2015) simulated the statistical power for case-control and discordant monozygotic twin EWAS study designs, using a range of epigenetic risk effect sizes and conditions. For example, to detect a $10 \%$ mean methylation difference between affected and unaffected subjects at a genome-wide significance threshold of $p=1 \times 10^{-6}, 98$ monozygotic twin pairs were required to reach $80 \%$ EWAS power, and 112 cases and 112 controls pairs were needed for the case-control design (Tsai and Bell 2015).

Additionally, many items require careful consideration in EWAS study design, such as population and tissue selection, population stratification, cell heterogeneity, confounding, temporality, appropriate statistical analysis, and validation of results (Saffari et al. 2018; Michels and Binder 2018). Moreover, it has been recently suggested that differential DNA methylation identified in peripheral blood may not correlate well with methylation changes in brain tissue (Ursini et al. 2011; Provençal et al. 2012; Wang et al. 2012). Further research is therefore needed to investigate whether DNA isolated from peripheral sources can be used as a surrogate biomarker for methylation patterns in the brain.

\section{Future perspectives}

RVAS and EWAS analyses can be adopted to elucidate missing heritability in PD; however, there are only a small number of reports of these analyses, and the evidence remains insufficient. To confidently identify or exclude rare variants or epigenetic changes in complex diseases, further analyses are required using sample sizes in the tens of thousands, extensive functional annotations, and highly targeted hypothesis testing.
Currently used NGS techniques have limitations for identifying structural variants, sequencing repetitive regions, phasing of alleles, and distinguishing highly homologous genomic regions because of its short-read lengths (Mantere et al. 2019). Recently, long-read-NGS (LR-NGS) has emerged, which is expected to improve the characterization of genetic variations and regions that are difficult to assess using prevailing NGS (Lu et al. 2016; Midha et al. 2019). Moreover, several studies have recently demonstrated that LR-NGS technology is ideal for epigenetic characterization (Nakano et al. 2017; Sakamoto et al. 2020). Genetic analyses using the latest technology, including LR-NGS, are expected to lead to the discovery of new PD causative genetic and epigenetic variations.

In the future, methodological progress may contribute to more robust findings that have a strong effect on PD onset and might also contribute to targeted preventive measures and the development of individualized therapeutic approaches. However, because of the higher disease risks that will be implicated in these findings, strict regulations about genetic counseling, confidentiality, and data protection should be applied (Gershon and AllieyRodriguez 2013). On a more positive note, the sharing of clinical and genomic data promises to increase research efficiency, expedite translational efforts of research results, and ensure the traceability and transparency of published studies (Shabani and Borry 2015; Takashima et al. 2018). In the post-GWAS era, the ethical framework regarding data sharing should require that researchers and research participants are responsible for protecting privacy, while advancing genomic science and medicine.

Acknowledgements We thank Bronwen Gardner, PhD, from Edanz Group (https://en-author-services.edanzgroup.com/) for editing the English text of a draft of this manuscript. This work was supported by a grant from the Takeda Science Foundation. 


\section{Compliance with ethical standards}

Conflict of interest The authors declare no conflicts of interest associated with this article.

Open Access This article is licensed under a Creative Commons Attribution 4.0 International License, which permits use, sharing, adaptation, distribution and reproduction in any medium or format, as long as you give appropriate credit to the original author(s) and the source, provide a link to the Creative Commons licence, and indicate if changes were made. The images or other third party material in this article are included in the article's Creative Commons licence, unless indicated otherwise in a credit line to the material. If material is not included in the article's Creative Commons licence and your intended use is not permitted by statutory regulation or exceeds the permitted use, you will need to obtain permission directly from the copyright holder. To view a copy of this licence, visit http://creativecommons.org/licenses/by/4.0/.

\section{References}

Abdulkadir M, Mathews CA, Scharf JM, Yu D, Tischfield JA, Heiman GA, Hoekstra PJ, Dietrich A (2019) Polygenic risk scores derived from a Tourette syndrome genome-wide association study predict presence of tics in the Avon Longitudinal Study of Parents and Children Cohort. Biol Psychiatry 85(4):298-304. https://doi. org/10.1016/j.biopsych.2018.09.011

Abdulrahim JW, Kwee LC, Grass E, Siegler IC, Williams R, Karra R, Kraus WE, Gregory SG, Shah SH (2019) Epigenome-wide association study for all-cause mortality in a cardiovascular cohort identifies differential methylation in castor zinc finger 1 (CASZ1). J Am Heart Assoc 8(21):e013228. https://doi.org/10.1161/ JAHA. 119.013228

Bandyopadhyay B, Chanda V, Wang Y (2017) Finding the sources of missing heritability within rare variants through simulation. Bioinform Biol Insights 11:1177932217735096. https://doi. org/10.1177/1177932217735096

Barnett IJ, Lee S, Lin X (2013) Detecting rare variant effects using extreme phenotype sampling in sequencing association studies. Genet Epidemiol 37(2):142-151. https://doi.org/10.1002/ gepi.21699

Baum AE, Akula N, Cabanero M, Cardona I, Corona W, Klemens B, Schulze TG, Cichon S, Rietschel M, Nöthen MM, Georgi A, Schumacher J, Schwarz M, Abou Jamra R, Höfels S, Propping P, Satagopan J, Detera-Wadleigh SD, Hardy J, McMahon FJ (2008) A genome-wide association study implicates diacylglycerol kinase eta (DGKH) and several other genes in the etiology of bipolar disorder. Mol Psychiatry 13(2):197-207

Bhattacharjee S, Rajaraman P, Jacobs KB, Wheeler WA, Melin BS, Hartge P, GliomaScan Consortium, Yeager M, Chung CC, Chanock SJ, Chatterjee N (2012) A subset-based approach improves power and interpretation for the combined analysis of genetic association studies of heterogeneous traits. Am J Hum Genet 90(5):821-835. https://doi.org/10.1016/j.ajhg.2012.03.015

Bonnet-Brilhault F, Alirol S, Blanc R, Bazaud S, Marouillat S, Thépault RA, Andres CR, Lemonnier É, Barthélémy C, Raynaud M, Toutain A, Gomot M, Laumonnier F (2016) GABA/Glutamate synaptic pathways targeted by integrative genomic and electrophysiological explorations distinguish autism from intellectual disability. Mol Psychiatry 21(3):411-418. https://doi.org/10.1038/ mp. 2015.75

Bourrat P, Lu Q, Jablonka E (2017) Why the missing heritability might not be in the DNA. Bioessays 39(7). doi:10.1002/bies.201700067
Bulik-Sullivan BK, Loh PR, Finucane HK, Ripke S, Yang J, Schizophrenia Working Group of the Psychiatric Genomics Consortium, Patterson N, Daly MJ, Price AL, Neale BM (2015) LD score regression distinguishes confounding from polygenicity in genome-wide association studies. Nat Genet 47(3):291-295. https ://doi.org/10.1038/ng.3211

Deckert J, Weber H, Villmann C, Lonsdorf TB, Richter J, Andreatta M, Arias-Vasquez A, Hommers L, Kent L, Schartner C, Cichon S, Wolf C, Schaefer N, von Collenberg CR, Wachter B, Blum R, Schümann D, Scharfenort R, Schumacher J, Forstner AJ, Baumann C, Schiele MA, Notzon S, Zwanzger P, Janzing JGE, Galesloot T, Kiemeney LA, Gajewska A, Glotzbach-Schoon E, Mühlberger A, Alpers G, Fydrich T, Fehm L, Gerlach AL, Kircher T, Lang T, Ströhle A, Arolt V, Wittchen HU, Kalisch R, Büchel C, Hamm A, Nöthen MM, Romanos M, Domschke K, Pauli P, Reif A (2017) GLRB allelic variation associated with agoraphobic cognitions, increased startle response and fear network activation: a potential neurogenetic pathway to panic disorder. Mol Psychiatry 22(10):1431-1439. https://doi. org/10.1038/mp.2017.2

Dennison CA, Legge SE, Pardiñas AF, Walters JTR (2019) Genomewide association studies in schizophrenia: recent advances, challenges and future perspective. Schizophr Res. https://doi. org/10.1016/j.schres.2019.10.048

Erhardt A, Czibere L, Roeske D, Lucae S, Unschuld PG, Ripke S, Specht M, Kohli MA, Kloiber S, Ising M, Heck A, Pfister H, Zimmermann P, Lieb R, Pütz B, Uhr M, Weber P, Deussing JM, Gonik M, Bunck M, Kebler MS, Frank E, Hohoff C, Domschke K, Krakowitzky P, Maier W, Bandelow B, Jacob C, Deckert J, Schreiber S, Strohmaier J, Nöthen M, Cichon S, Rietschel M, Bettecken T, Keck ME, Landgraf R, Müller-Myhsok B, Holsboer F, Binder EB (2011) TMEM132D, a new candidate for anxiety phenotypes: evidence from human and mouse studies. Mol Psychiatry 16(6):647-663. https://doi.org/10.1038/mp.2010.41

Erhardt A, Akula N, Schumacher J, Czamara D, Karbalai N, MüllerMyhsok B, Mors O, Borglum A, Kristensen AS, Woldbye DP, Koefoed P, Eriksson E, Maron E, Metspalu A, Nurnberger J, Philibert RA, Kennedy J, Domschke K, Reif A, Deckert J, Otowa T, Kawamura Y, Kaiya H, Okazaki Y, Tanii H, Tokunaga K, Sasaki T, Ioannidis JP, McMahon FJ, Binder EB (2012) Replication and meta-analysis of TMEM132D gene variants in panic disorder. Transl Psychiatry 2:e156. https://doi.org/10.1038/tp.2012.85

Flanagan JM (2015) Epigenome-wide association studies (EWAS): past, present, and future. Methods Mol Biol 1238:51-63. https:// doi.org/10.1007/978-1-4939-1804-1_3

Forstner AJ, Awasthi S, Wolf C, Maron E, Erhardt A, Czamara D, Eriksson E, Lavebratt C, Allgulander C, Friedrich N, Becker J, Hecker J, Rambau S, Conrad R, Geiser F, McMahon FJ, Moebus S, Hess T, Buerfent BC, Hoffmann P, Herms S, HeilmannHeimbach S, Kockum I, Olsson T, Alfredsson L, Weber H, Alpers GW, Arolt V, Fehm L, Fydrich T, Gerlach AL, Hamm A, Kircher T, Pané-Farré CA, Pauli P, Rief W, Ströhle A, Plag J, Lang T, Wittchen HU, Mattheisen M, Meier S, Metspalu A, Domschke K, Reif A, Hovatta I, Lindefors N, Andersson E, Schalling M, Mbarek H, Milaneschi Y, de Geus EJC, Boomsma DI, Penninx BWJH, Thorgeirsson TE, Steinberg S, Stefansson K, Stefansson $\mathrm{H}$, Müller-Myhsok B, Hansen TF, Børglum AD, Werge T, Mortensen PB, Nordentoft M, Hougaard DM, Hultman CM, Sullivan PF, Nöthen MM, Woldbye DPD, Mors O, Binder EB, Rück C, Ripke S, Deckert J, Schumacher J (2019) Genome-wide association study of panic disorder reveals genetic overlap with neuroticism and depression. Mol Psychiatry. https://doi.org/10.1038/ s41380-019-0590-2

Fromer M, Pocklington AJ, Kavanagh DH, Williams HJ, Dwyer S, Gormley P, Georgieva L, Rees E, Palta P, Ruderfer DM, Carrera N, Humphreys I, Johnson JS, Roussos P, Barker DD, Banks 
E, Milanova V, Grant SG, Hannon E, Rose SA, Chambert K, Mahajan M, Scolnick EM, Moran JL, Kirov G, Palotie A, McCarroll SA, Holmans P, Sklar P, Owen MJ, Purcell SM, O'Donovan MC (2014) De novo mutations in schizophrenia implicate synaptic networks. Nature 506(7487):179-184. https://doi.org/10.1038/ nature 12929

Gasse C, Wimberley T, Wang Y, Mors O, Børglum A, Als TD, Werge T, Nordentoft M, Hougaard DM, Horsdal HT (2019) Schizophrenia polygenic risk scores, urbanicity and treatment-resistant schizophrenia. Schizophr Res 212:79-85. https://doi.org/10.1016/j. schres.2019.08.008

Gershon ES, Alliey-Rodriguez N (2013) New ethical issues for genetic counseling in common mental disorders. Am J Psychiatry 170:968-976. https://doi.org/10.1176/appi.ajp.2013.12121558

Goldstein RB, Wickramaratne PJ, Horwath E, Weissman MM (1997) Familial aggregation and phenomenology of 'early'-onset (at or before age 20 years) panic disorder. Arch Gen Psychiatry 54(3):271-278. https://doi.org/10.1001/archpsyc.1997.01830 150097014

Gonzalez-Jaramillo V, Portilla-Fernandez E, Glisic M, Voortman T, Bramer W, Chowdhury R, Roks AJM, Jan Danser AH, Muka T, Nano J, Franco OH (2019) The role of DNA methylation and histone modifications in blood pressure: a systematic review. $\mathrm{J}$ Hum Hypertens 33(10):703-715. https://doi.org/10.1038/s4137 1-019-0218-7

Gratacòs M, Costas J, de Cid R, Bayés M, González JR, Baca-García E, de Diego Y, Fernández-Aranda F, Fernández-Piqueras J, Guitart M, Martín-Santos R, Martorell L, Menchón JM, Roca M, Sáiz-Ruiz J, Sanjuán J, Torrens M, Urretavizcaya M, Valero J, Vilella E, Estivill X, Carracedo A, Psychiatric Genetics Network Group (2009) Identification of new putative susceptibility genes for several psychiatric disorders by association analysis of regulatory and non-synonymous SNPs of 306 genes involved in neurotransmission and neurodevelopment. Am J Med Genet B Neuropsychiatr Genet 150B(6):808-816. https:// doi.org/10.1002/ajmg.b.30902

Gregersen NO, Lescai F, Liang J, Li Q, Als T, Buttenschøn HN, Hedemand A, Biskopst $\varnothing \mathrm{M}$, Wang J, Wang AG, Børglum AD, Mors O, Demontis D (2016) Whole-exome sequencing implicates DGKH as a risk gene for panic disorder in the Faroese population. Am J Med Genet B Neuropsychiatr Genet 171(8):1013-1022. https:// doi.org/10.1002/ajmg.b.32464

Hettema JM, Neale MC, Kendler KS (2001) A review and metaanalysis of the genetic epidemiology of anxiety disorders. Am J Psychiatry 158(10):1568-1578. https://doi.org/10.1176/appi. ajp. 158.10 .1568

Hodgson K, Almasy L, Knowles EE, Kent JW, Curran JE, Dyer TD, Göring HH, Olvera RL, Fox PT, Pearlson GD, Krystal JH, Duggirala R, Blangero J, Glahn DC (2016) Genome-wide significant loci for addiction and anxiety. Eur Psychiatry 36:47-54. https:// doi.org/10.1016/j.eurpsy.2016.03.004

Inoue A, Akiyoshi J, Muronaga M, Masuda K, Aizawa S, Hirakawa H, Ishitobi Y, Higuma H, Maruyama Y, Ninomiya T, Tanaka Y, Hanada H, Kawano Y (2015) Association of TMEM132D, COMT, and GABRA6 genotypes with cingulate, frontal cortex and hippocampal emotional processing in panic and major depressive disorder. Int J Psychiatry Clin Pract 19(3):192-200. https:// doi.org/10.3109/13651501.2015.1043133

Iurato S, Carrillo-Roa T, Arloth J, Czamara D, Diener-Hölzl L, Lange J, Müller-Myhsok B, Binder EB, Erhardt A (2017) DNA methylation signatures in panic disorder. Transl Psychiatry 7(12):1287. https://doi.org/10.1038/s41398-017-0026-1

Karayiorgou M, Gogos JA (2006) Schizophrenia genetics: uncovering positional candidate genes. Eur J Hum Genet 14(5):512-519. https ://doi.org/10.1038/sj.ejhg.5201587
Klengel T, Binder EB (2015) Epigenetics of stress-related psychiatric disorders and gene $\times$ environment interactions. Neuron 86(6):1343-1357. https://doi.org/10.1016/j.neuron.2015.05.036

Langenberg C, Lotta LA (2018) Genomic insights into the causes of type 2 diabetes. Lancet 391(10138):2463-2474. https://doi. org/10.1016/S0140-6736(18)31132-2

Li YR, Keating BJ (2014) Trans-ethnic genome-wide association studies: advantages and challenges of mapping in diverse populations. Genome Med 6(10):91. https://doi.org/10.1186/s1307 3-014-0091-5

Lu H, Giordano F, Ning Z (2016) Oxford nanopore MinION sequencing and genome assembly. Genom Proteom Bioinform 14(5):265279. https://doi.org/10.1016/j.gpb.2016.05.004

Maher B (2008) Personal genomes: the case of the missing heritability. Nature 456(7218):18-21. https://doi.org/10.1038/456018a

Mantere T, Kersten S, Hoischen A (2019) Long-read sequencing emerging in medical genetics. Front Genet 10:426. https://doi. org/10.3389/fgene.2019.00426

Markowitz JS, Weissman MM, Ouellette R, Lish JD, Klerman GL (1989) Quality of life in panic disorder. Arch Gen Psychiatry 46(11):984-992

McCarthy NS, Melton PE, Ward SV, Allan SM, Dragovic M, Clark ML, Morar B, Rubio JP, Blangero J, Badcock JC, Morgan VA, Moses EK, Jablensky A (2017) Exome array analysis suggests an increased variant burden in families with schizophrenia. Schizophr Res 185:9-16. https://doi.org/10.1016/j.schres.2016.12.007

Medina-Gomez C, Felix JF, Estrada K, Peters MJ, Herrera L, Kruithof CJ, Duijts L, Hofman A, van Duijn CM, Uitterlinden AG, Jaddoe VW, Rivadeneira F (2015) Challenges in conducting genomewide association studies in highly admixed multi-ethnic populations: the Generation R Study. Eur J Epidemiol 30(4):317-330. https://doi.org/10.1007/s10654-015-9998-4

Meier SM, Deckert J (2019) Genetics of anxiety disorders. Curr Psychiatry Rep 21(3):16. https://doi.org/10.1007/s11920-019-1002-7

Michels KB, Binder AM (2018) Considerations for design and analysis of DNA methylation studies. Methods Mol Biol 1708:31-46. https ://doi.org/10.1007/978-1-4939-7481-8_2

Mick E, McGough J, Loo S, Doyle AE, Wozniak J, Wilens TE, Smalley S, McCracken J, Biederman J, Faraone SV (2011) Genome-wide association study of the child behavior checklist dysregulation profile. J Am Acad Child Adolesc Psychiatry 50(8):807-817.e8. https://doi.org/10.1016/j.jaac.2011.05.001

Midha MK, Wu M, Chiu KP (2019) Long-read sequencing in deciphering human genetics to a greater depth. Hum Genet 138(1112):1201-1215. https://doi.org/10.1007/s00439-019-02064-y

Morimoto Y, Shimada-Sugimoto M, Otowa T, Yoshida S, Kinoshita A, Mishima H, Yamaguchi N, Mori T, Imamura A, Ozawa H, Kurotaki N, Ziegler C, Domschke K, Deckert J, Umekage T, Tochigi M, Kaiya H, Okazaki Y, Tokunaga K, Sasaki T, Yoshiura KI, Ono S (2018) Whole-exome sequencing and gene-based rare variant association tests suggest that PLA2G4E might be a risk gene for panic disorder. Transl Psychiatry 8(1):41. https://doi.org/10.1038/ s41398-017-0088-0

Morris AP (2011) Transethnic meta-analysis of genomewide association studies. Genet Epidemiol 35(8):809-822. https://doi. org/10.1002/gepi.20630

Moutsianas L, Agarwala V, Fuchsberger C, Flannick J, Rivas MA, Gaulton KJ, Albers PK, GoT2D Consortium, McVean G, Boehnke M, Altshuler D, McCarthy MI (2015) The power of gene-based rare variant methods to detect disease-associated variation and test hypotheses about complex disease. PLoS Genet 11(4):e1005165. https://doi.org/10.1371/journal.pgen.1005165

Nakano K, Shiroma A, Shimoji M, Tamotsu H, Ashimine N, Ohki S, Shinzato M, Minami M, Nakanishi T, Teruya K, Satou K, Hirano T (2017) Advantages of genome sequencing by long-read 
sequencer using SMRT technology in medical area. Hum Cell 30(3):149-161. https://doi.org/10.1007/s13577-017-0168-8

Otowa T, Yoshida E, Sugaya N, Yasuda S, Nishimura Y, Inoue K, Tochigi M, Umekage T, Miyagawa T, Nishida N, Tokunaga K, Tanii H, Sasaki T, Kaiya H, Okazaki Y (2009) Genome-wide association study of panic disorder in the Japanese population. $\mathrm{J}$ Hum Genet 54(2):122-126. https://doi.org/10.1038/jhg.2008.17

Otowa T, Tanii H, Sugaya N, Yoshida E, Inoue K, Yasuda S, Shimada T, Kawamura Y, Tochigi M, Minato T, Umekage T, Miyagawa T, Nishida N, Tokunaga K, Okazaki Y, Kaiya H, Sasaki T (2010) Replication of a genomewide association study of panic disorder in a Japanese population. J Hum Genet 55(2):91-96. https://doi. org/10.1038/jhg.2009.127

Otowa T, Kawamura Y, Nishida N, Sugaya N, Koike A, Yoshida E, Inoue K, Yasuda S, Nishimura Y, Liu X, Konishi Y, Nishimura F, Shimada T, Kuwabara H, Tochigi M, Kakiuchi C, Umekage T, Miyagawa T, Miyashita A, Shimizu E, Akiyoshi J, Someya T, Kato T, Yoshikawa T, Kuwano R, Kasai K, Kato N, Kaiya H, Tokunaga K, Okazaki Y, Tanii H, Sasaki T (2012) Metaanalysis of genome-wide association studies for panic disorder in the Japanese population. Transl Psychiatry 2:e186. https://doi. org/10.1038/tp.2012.89

Otowa T, Hek K, Lee M, Byrne EM, Mirza SS, Nivard MG, Bigdeli T, Aggen SH, Adkins D, Wolen A, Fanous A, Keller MC, Castelao E, Kutalik Z, Van der Auwera S, Homuth G, Nauck M, Teumer A, Milaneschi Y, Hottenga JJ, Direk N, Hofman A, Uitterlinden A, Mulder CL, Henders AK, Medland SE, Gordon S, Heath AC, Madden PA, Pergadia ML, van der Most PJ, Nolte IM, van Oort FV, Hartman CA, Oldehinkel AJ, Preisig M, Grabe HJ, Middeldorp CM, Penninx BW, Boomsma D, Martin NG, Montgomery G, Maher BS, van den Oord EJ, Wray NR, Tiemeier H, Hettema JM (2016) Meta-analysis of genome-wide association studies of anxiety disorders. Mol Psychiatry 21(10):1391-1399. https://doi. org/10.1038/mp.2015.197

Portela A, Esteller M (2010) Epigenetic modifications and human disease. Nat Biotechnol 28(10):1057-1068. https://doi.org/10.1038/ nbt. 1685

Provençal N, Suderman MJ, Guillemin C, Massart R, Ruggiero A, Wang D, Bennett AJ, Pierre PJ, Friedman DP, Côté SM, Hallett M, Tremblay RE, Suomi SJ, Szyf M (2012) The signature of maternal rearing in the methylome in rhesus macaque prefrontal cortex and T cells. J Neurosci 32(44):15626-15642. https://doi. org/10.1523/JNEUROSCI.1470-12.2012

Purves KL, Coleman JRI, Meier SM, Rayner C, Davis KAS, Cheesman R, Bækvad-Hansen M, Børglum AD, Wan Cho S, Jürgen Deckert J, Gaspar HA, Bybjerg-Grauholm J, Hettema JM, Hotopf M, Hougaard D, Hübel C, Kan C, McIntosh AM, Mors O, Bo Mortensen P, Nordentoft M, Werge T, Nicodemus KK, Mattheisen M, Breen G, Eley TC (2019) A major role for common genetic variation in anxiety disorders. Mol Psychiatry. https://doi.org/10.1038/s4138 0-019-0559-1

Saffari A, Silver MJ, Zavattari P, Moi L, Columbano A, Meaburn EL, Dudbridge F (2018) Estimation of a significance threshold for epigenome-wide association studies. Genet Epidemiol 42(1):20-33. https://doi.org/10.1002/gepi.22086

Sakamoto Y, Sereewattanawoot S, Suzuki A (2020) A new era of longread sequencing for cancer genomics. J Hum Genet 65(1):3-10. https://doi.org/10.1038/s10038-019-0658-5

Sanders SJ (2019) Next-generation sequencing in autism spectrum disorder. Cold Spring Harb Perspect Med. https://doi.org/10.1101/ cshperspect.a026872

Schiele MA, Domschke K (2018) Epigenetics at the crossroads between genes, environment and resilience in anxiety disorders. Genes Brain Behav 17(3):e12423. https://doi.org/10.1111/gbb.12423

Schiele MA, Gottschalk MG, Domschke K (2020) The applied implications of epigenetics in anxiety, affective and stress-related disorders-a review and synthesis on psychosocial stress, psychotherapy and prevention. Clin Psychol Rev 77:101830. https:// doi.org/10.1016/j.cpr.2020.101830

Schumacher J, Kristensen AS, Wendland JR, Nöthen MM, Mors O, McMahon FJ (2011) The genetics of panic disorder. J Med Genet 48(6):361-368. https://doi.org/10.1136/jmg.2010.086876

Shabani M, Borry P (2015) Challenges of web-based personal genomic data sharing. Life Sci Soc Policy 11:3. https://doi.org/10.1186/ s40504-014-0022-7

Shimada-Sugimoto M, Otowa T, Miyagawa T, Umekage T, Kawamura Y, Bundo M, Iwamoto K, Tochigi M, Kasai K, Kaiya H, Tanii H, Okazaki Y, Tokunaga K, Sasaki T (2017) Epigenome-wide association study of DNA methylation in panic disorder. Clin Epigenet 9:6. https://doi.org/10.1186/s13148-016-0307-1

Singer JB (2009) Candidate gene association analysis. Methods Mol Biol 573:223-230. https://doi.org/10.1007/978-1-60761-247-6_13

Singh T, Kurki MI, Curtis D, Purcell SM, Crooks L, McRae J, Suvisaari J, Chheda H, Blackwood D, Breen G, Pietiläinen O, Gerety SS, Ayub M, Blyth M, Cole T, Collier D, Coomber EL, Craddock N, Daly MJ, Danesh J, DiForti M, Foster A, Freimer NB, Geschwind D, Johnstone M, Joss S, Kirov G, Körkkö J, Kuismin O, Holmans P, Hultman CM, Iyegbe C, Lönnqvist J, Männikkö M, McCarroll SA, McGuffin P, McIntosh AM, McQuillin A, Moilanen JS, Moore C, Murray RM, Newbury-Ecob R, Ouwehand W, Paunio T, Prigmore E, Rees E, Roberts D, Sambrook J, Sklar P, St Clair D, Veijola J, Walters JT, Williams H, Swedish Schizophrenia Study, INTERVAL Study, DDD Study, UK10 K Consortium, Sullivan PF, Hurles ME, O'Donovan MC, Palotie A, Owen MJ, Barrett JC (2016) Rare loss-of-function variants in SETD1A are associated with schizophrenia and developmental disorders. Nat Neurosci 19(4):571-577. https://doi.org/10.1038/nn.4267

Starnawska A, Tan Q, Soerensen M, McGue M, Mors O, Børglum AD, Christensen K, Nyegaard M, Christiansen L (2019) Epigenome-wide association study of depression symptomatology in elderly monozygotic twins. Transl Psychiatry 9(1):214. https:// doi.org/10.1038/s41398-019-0548-9

Stein MB, Chen CY, Jain S, Jensen KP, He F, Heeringa SG, Kessler RC, Maihofer A, Nock MK, Ripke S, Sun X, Thomas ML, Ursano RJ, Smoller JW, Gelernter J, Collaborators ASTARRS (2017) Genetic risk variants for social anxiety. Am J Med Genet B Neuropsychiatr Genet 174(2):120-131. https://doi.org/10.1002/ ajmg.b. 32520

Stephens M, Balding DJ (2009) Bayesian statistical methods for genetic association studies. Nat Rev Genet 10(10):681-690. https://doi. org/10.1038/nrg2615

Szymczak S, Biernacka JM, Cordell HJ, González-Recio O, König IR, Zhang H, Sun YV (2009) Machine learning in genome-wide association studies. Genet Epidemiol 33(Suppl 1):S51-57. https ://doi.org/10.1002/gepi.20473

Takashima K, Maru Y, Mori S, Mano H, Noda T, Muto K (2018) Ethical concerns on sharing genomic data including patients' family members. BMC Med Ethics 19(1):61. https://doi.org/10.1186/ s12910-018-0310-5

Takata A, Xu B, Ionita-Laza I, Roos JL, Gogos JA, Karayiorgou M (2014) Loss-of-function variants in schizophrenia risk and SETD1A as a candidate susceptibility gene. Neuron 82(4):773780. https://doi.org/10.1016/j.neuron.2014.04.043

Tam V, Patel N, Turcotte M, Bossé Y, Paré G, Meyre D (2019) Benefits and limitations of genome-wide association studies. Nat Rev Genet 20(8):467-484. https://doi.org/10.1038/s41576-019-0127-1

Tang J, Chen X, Cai B, Chen G (2019) A logical relationship for schizophrenia, bipolar, and major depressive disorder. Part 4: evidence from chromosome 4 high-density association screen. J Comp Neurol 527(2):392-405. https://doi.org/10.1002/cne.24543

Tomasi J, Lisoway AJ, Zai CC, Harripaul R, Müller DJ, Zai GCM, McCabe RE, Richter MA, Kennedy JL, Tiwari AK (2019) 
Towards precision medicine in generalized anxiety disorder: review of genetics and pharmaco(epi)genetics. J Psychiatr Res 119:33-47. https://doi.org/10.1016/j.jpsychires.2019.09.002

Trerotola M, Relli V, Simeone P, Alberti S (2015) Epigenetic inheritance and the missing heritability. Hum Genom 9:17. https://doi. org/10.1186/s40246-015-0041-3

Tsai PC, Bell JT (2015) Power and sample size estimation for epigenome-wide association scans to detect differential DNA methylation. Int J Epidemiol 44(4):1429-1441. https://doi.org/10.1093/ ije/dyv041

Uniken Venema WT, Voskuil MD, Dijkstra G, Weersma RK, Festen EA (2017) The genetic background of inflammatory bowel disease: from correlation to causality. J Pathol 241(2):146-158. https ://doi.org/10.1002/path.4817

Ursini G, Bollati V, Fazio L, Porcelli A, Iacovelli L, Catalani A, Sinibaldi L, Gelao B, Romano R, Rampino A, Taurisano P, Mancini M, Di Giorgio A, Popolizio T, Baccarelli A, De Blasi A, Blasi G, Bertolino A (2011) Stress-related methylation of the catecholO-methyltransferase Val 158 allele predicts human prefrontal cognition and activity. J Neurosci 31(18):6692-6698. https://doi. org/10.1523/JNEUROSCI.6631-10.2011

van der Sluis S, Verhage M, Posthuma D, Dolan CV (2010) Phenotypic complexity, measurement bias, and poor phenotypic resolution contribute to the missing heritability problem in genetic association studies. PLoS ONE 5(11):e13929. https://doi.org/10.1371/ journal.pone.0013929

Venken T, Del-Favero J (2007) Chasing genes for mood disorders and schizophrenia in genetically isolated populations. Hum Mutat 28(12):1156-1170. https://doi.org/10.1002/humu.20582

Visscher PM, Wray NR, Zhang Q, Sklar P, McCarthy MI, Brown MA, Yang J (2017) 10 Years of GWAS discovery: biology, function, and translation. Am J Hum Genet 101(1):5-22. https://doi. org/10.1016/j.ajhg.2017.06.005

Wang D, Szyf M, Benkelfat C, Provençal N, Turecki G, Caramaschi D, Côté SM, Vitaro F, Tremblay RE, Booij L (2012) Peripheral SLC6A4 DNA methylation is associated with in vivo measures of human brain serotonin synthesis and childhood physical aggression. PLoS ONE 7(6):e39501. https://doi.org/10.1371/journ al.pone. 0039501

Weber H, Kittel-Schneider S, Gessner A, Domschke K, Neuner M, Jacob CP, Buttenschon HN, Boreatti-Hümmer A, Volkert J, Herterich S, Baune BT, Gross-Lesch S, Kopf J, Kreiker S, Nguyen TT, Weissflog L, Arolt V, Mors O, Deckert J, Lesch KP, Reif A (2011) Cross-disorder analysis of bipolar risk genes: further evidence of DGKH as a risk gene for bipolar disorder, but also unipolar depression and adult ADHD. Neuropsychopharmacology 36(10):2076-2085. https://doi.org/10.1038/npp.2011.98

Wittchen HU, Jacobi F, Rehm J, Gustavsson A, Svensson M, Jönsson B, Olesen J, Allgulander C, Alonso J, Faravelli C, Fratiglioni L, Jennum P, Lieb R, Maercker A, van Os J, Preisig M, SalvadorCarulla L, Simon R, Steinhausen HC (2011) The size and burden of mental disorders and other disorders of the brain in Europe 2010. Eur Neuropsychopharmacol 21(9):655-679. https://doi. org/10.1016/j.euroneuro.2011.07.018

Yosifova A, Mushiroda T, Kubo M, Takahashi A, Kamatani Y, Kamatani N, Stoianov D, Vazharova R, Karachanak S, Zaharieva I, Dimova I, Hadjidekova S, Milanova V, Madjirova N, Gerdjikov I, Tolev T, Poryazova N, O’Donovan MC, Owen MJ, Kirov G, Toncheva D, Nakamura Y (2011) Genome-wide association study on bipolar disorder in the Bulgarian population. Genes Brain Behav 10(7):789-797. https://doi.org/10.1111/j.1601183X.2011.00721.X

Zeng Z, Wang T, Li T, Li Y, Chen P, Zhao Q, Liu J, Li J, Feng G, He L, Shi Y (2011) Common SNPs and haplotypes in DGKH are associated with bipolar disorder and schizophrenia in the Chinese Han population. Mol Psychiatry 16(5):473-475. https://doi. org/10.1038/mp.2010.86

Zhuo C, Hou W, Li G, Mao F, Li S, Lin X, Jiang D, Xu Y, Tian H, Wang W, Cheng L (2019) The genomics of schizophrenia: shortcomings and solutions. Prog Neuropsychopharmacol Biol Psychiatry 93:71-76. https://doi.org/10.1016/j.pnpbp.2019.03.009

Ziegler C, Grundner-Culemann F, Schiele MA, Schlosser P, Kollert L, Mahr M, Gajewska A, Lesch KP, Deckert J, Köttgen A, Domschke K (2019) The DNA methylome in panic disorder: a case-control and longitudinal psychotherapy-epigenetic study. Transl Psychiatry 9(1):314. https://doi.org/10.1038/s41398-019-0648-6

Zuk O, Schaffner SF, Samocha K, Do R, Hechter E, Kathiresan S, Daly MJ, Neale BM, Sunyaev SR, Lander ES (2014) Searching for missing heritability: designing rare variant association studies. Proc Natl Acad Sci USA 111(4):E455-E464. https://doi. org/10.1073/pnas.1322563111

Publisher's Note Springer Nature remains neutral with regard to jurisdictional claims in published maps and institutional affiliations. 